\title{
Achieving Economic Dynamism in China
}

\author{
Edmund Phelps
}

\begin{abstract}
Innovation is driven by having a high degree of market competition, governmental support of education, efficiency-enhancing regulations, and a legal structure that supports property rights. Innovation also depends on society having people with both the desire and opportunity to exercise their creativity and their inventiveness by coming up with original ideas and the entrepreneurial spirit to build businesses based on those ideas. China has long had high growth rates based on catching up to the world standard technologies. If China is to make the next big leap from a middle-income country into a high-income country, then China will need to both promote indigenous innovation and continue improving its institutions. But, at least as importantly, it will have to foster creativity, originality, exploration, and entrepreneurship. China has taken big steps to encourage entrepreneurship in big cities, in rural areas and small cities, and that is great. Yet, it's one thing to realize today's standards of productivity, and it's another thing to be generating new stuff all the time. China is going to need people who demonstrate their creativity by conceiving and introducing original things. Only this kind of indigenous innovation can lead to permanent growth.
\end{abstract}

Keywords Indigenous innovation - Dynamism - Mass entrepreneurship · Mass flourishing $\cdot$ Economic institutions $\cdot$ Creativity $\cdot$ Economic reform $\cdot$ Middle-income trap $\cdot$ Technological catch-up $\cdot$ Originality $\cdot$ Exploration $\cdot$ Stagnation $\cdot$ Job satisfaction $\cdot$ Productivity

Innovation depends not just on having a high degree of market competition, governmental support of education, efficiency-enhancing regulations, and a legal structure that supports property rights. It also depends on society having people, with both the desire and opportunity, to exercise their creativity and their inventiveness by coming up with original ideas, and the entrepreneurial spirit to build businesses based on those ideas.

If China is to make the big leap from a middle-income country, that has long had high growth rates based on catching up to the world standard technologies into a

\footnotetext{
E. Phelps (凶)

Columbia University, New York, USA

(C) The Author(s) 2021

H. Wang and A. Michie (eds.), Consensus or Conflict?, China and Globalization, https://doi.org/10.1007/978-981-16-5391-9_32
} 
high-income country with indigenous innovation, it certainly will have to continue improving its institutions. But, at least as importantly, it will have to foster creativity, originality, exploration and entrepreneurship.

The 2020 book, "Dynamism: The Values that Drive Innovation, Job Satisfaction, and Economic Growth," shows that indigenous innovation is rare and difficult to achieve. From the 1820 s to 1960 s, such innovation fundamentally changed the world economy and vastly improved living standards, first in Britain, then later in the United States, Germany and France. But, since 1945, innovation was largely driven by the United States-with little indigenous innovation even in continental Europe. And, starting in the 1970s, the economy-wide rate of innovation in the United States has slowed sharply. Today's Western nations will not be able to resume rapid growth and innovation unless they regain the spirit of originality and exploration.

In the vast majority of countries, imported innovation contributes more to productivity than indigenous innovation. That is as true of Sweden or France as it is of China, and it should be no surprise. After the launch of reform and opening-up policies starting in the late 1970s, China's innovation was predominantly imported.

But, China's sheer size might drive the need for it to stop relying on transferred technology and put more emphasis on self-directed, self-generated indigenous innovation, which, in turn, must be driven by a culture that fosters economic dynamism. As China runs out of foreign innovations it can import at an acceptable cost, its focus is now on indigenous innovation. The shift in focus in recent years from "Made in China" to "Created in China" is essential to continuing growth and transformation.

This paper does not propose to discuss all, or even most, of the issues outstanding between the world's two largest economies. It will focus, rather, on one decisive issue that bears on these tensions, namely innovation and its expression in economic development. Standard Western economic theory does not provide an adequate framework for evaluating China's challenges and opportunities, or the interaction of China with the rest of the world. Part of the source of misunderstanding between the United States and China stems from deficiencies in economic theory. A better theory-a theory of economic dynamism that leads to a better understanding of technological and economic innovation - can contribute to improved policy deliberation on US-Chinese economic relations.

It is critical to recognize that innovation is not a one-way street. China's indigenous innovation can be a spur to other world economies, which are still in the midst of a long period of declining innovation. No one can foresee the magnitude of the contribution to the world's economy by China's innovators, but I am sure they will make a significant contribution to the global economy.

\footnotetext{
1 'Dynamism-The Values That Drive Innovation, Job Satisfaction, and Economic Growth' written by Edmund S. Phelps, Raicho Bojilov, Hian Teck Hoon, and Gylfi Zoega was published by Harvard University Press in 2020.
} 


\section{Reforms Point in the Right Direction, but More Are Needed}

In his speech at the Boao Forum in 2018, President Xi Jinping spoke of China's entering a new era of openness. Under his leadership, initiatives have been taken to boost innovation through entrepreneurship, and his discussion of "quality growth" focuses on achieving indigenous innovation.

Also, Premier Li Keqiang has spearheaded a movement to encourage the massive formation of new companies, thus providing vehicles for business people possessing innovative ideas. The process for forming a new company has been shortened, leading to an increase in the number of enterprises. Importantly, Li's policy of shuang chuang, innovation and mass entrepreneurship, has filtered down to local governments all around the country. Many local government officials certainly see themselves as promoters of entrepreneurship.

Vice-Premier Liu He has got behind a policy to refrain from rescuing moribund enterprises, of which there are more than a few in the State sector. This should free up individuals to start new companies, and existing companies to enter new industries. Competition solves a lot of problems - a point that is increasingly lost on the West. The key insight is that when existing enterprises are protected from new market entrants bearing new ideas, the result will be less innovation and also less "adaptation" to a changing world, to use Friedrich Hayek's term.

China's total factor productivity growth rate, which had slowed for a while, picked up after the implementation of the new policies promoting entrepreneurship, encouraging new entrants, enforcing antitrust rules, and allowing state-owned enterprises to fail.

In recent years, China's government has encouraged the creation of a new stock exchange for high-technology start-ups-the Shanghai Stock Exchange Science and Technology Innovation Board, or STAR. But, the continuing development of a financial sector oriented toward business investment by private enterprises will be necessary.

Also of note is the huge increase in the participation of foreign experts in the Chinese economy, leading to a cross-pollinization of ideas.

Monopolization is a factor in the decline of new business start-ups in the United States and in the reduction in innovation. Monopolies need to be broken up or otherwise limited in their market power. It has been said that China is going in the right direction on this.

All this is fine, but there should be a bit more emphasis on the mass innovation part of the equation. China has many, many people with new ideas, which could be used by hard-driving guys who play the entrepreneurial role. Practicing entrepreneurship is great-it's an absolutely necessary thing to do-but it will be important that people can demonstrate their originality by conceiving and producing new things. 


\section{Mass Education that Encourages Creativity is Key}

China has built a vast number of schools, where Chinese children learn more about the world they will face. It has built a university system with many institutions ranking among the world's top 50 engineering schools, and it now graduates six times as many engineers and computer scientists as the United States.

Richard Nelson and I argued in 1966 that the diffusion of technical advances is hastened by investment in human capital through education. Since educational levels vary widely among countries, an improvement in education levels, that is, a deepening of human capital, allows the more developing countries to quickly import innovations created elsewhere-to catch up.

Of course, a lot of people have done a lot of things without having a great deal of formal education. But, if you want innovation all over the place, you also need to have education all over the place. And, for China to take the next step toward indigenous innovation, it needs to be education that encourages and inspires creativity.

Dynamism has to start in the school system, as early as primary school. Many children pick up musical instruments around the fifth or sixth grade, even earlier. It is perhaps not a coincidence that many Nobel Prize winners have played musical instruments. One suggestion for Chinese schools is that they give considerable attention to reading fiction and poetry and to the arts in general. It is important to encourage school children to exercise their creativity by challenging them to create original things. If that's done on a mass scale in China, there will be fruits of innovation.

Children need to have the opportunity to tinker - to build and repair things. To take a thing apart to see how it works. This applies to ideas as well as physical things. Composers might tinker a little bit before they are satisfied with the theme that they go on to develop. When the light bulb turns on and you have the idea, that's just the beginning. You then have to do a little bit of mucking around, a little testing, to see whether the idea will work. I think tinkering is integral to conceiving and implementing something on a practical level. Children need opportunities to practice this kind of tinkering.

Opportunities to be creative cannot be limited to an elite few, they need to be widespread throughout society. In the places and times when innovation was rapid and things were good, all sorts of people from all walks of life were huge contributors. For China to sustain rapid innovation, it is going to be important that the country enlists a wide swath of the population, not just a few million super-bright guys and gals in high-tech companies. The main theme of the 2013 book Mass Flourishing ${ }^{2}$ is that widespread flourishing depends on grassroots innovation from the bottom up.

Development of the Western areas of China has the potential of serving as a powerful source of new waves of development and probably innovation. But that will not happen without continued emphasis on raising the educational and health levels of people in those areas. This could lead to a great increase in the average human capital in the country.

\footnotetext{
2“Mass Flourishing: How Grassroots Innovation Created Jobs, Challenge, and Change" written by Edmund S. Phelps and published by Princeton University Press in 2013.
} 
China has been progressive toward women, but I think there is still a lot of space for women to do more and to become more active in businesses in China. They have an intuition that men do not have and they have a different perspective on the nation and the world. Women can add their intelligence and pragmatism to the pool of innovators. Adding them to the economy adds new ideas and new productivity gains.

\section{More International Opening-Up is Needed}

China also needs to continue to reinforce its policies of opening-up its markets to foreign competition. The Chinese authorities have recognized the importance of allowing more competition in the economy. By co-founding the Regional Comprehensive Economic Partnership, a trade association of 16 Asian countries, it has committed China to drastic reductions in tariffs for manufactured goods from Japan, South Korea and other countries that will compete with Chinese manufacturers.

Furthermore, China often uses a so-called "catfishing" strategy in which it strongly welcomes foreign competitors into the Chinese domestic market to force domestic firms to reach world-class standards. Tesla and Apple are examples of that.

Even so, economic and diplomatic disputes will continue to simmer. The recent trade dispute is about high tariffs and other hurdles that US companies feel they are faced with as they contemplate attempting to enter Chinese markets. China can reply that the European Union also has some pretty high tariffs, but it may be that the non-tariff obstacles are not as daunting in Europe as they are in China.

The real underlying problem is that some sectors of a national economy are hurt more than they are helped by free trade. So, all countries engage in protectionism. And China's protectionism hurts the interests of the United States, just as US protectionism hurts Chinese interests. In the United States, it is low-skilled labor that is hurt most. US administrations, regardless of party affiliation, cannot ignore stagnant wages and the resulting social pathologies, which are so well documented by Anne Case, Angus Deaton, and Robert Putnam. ${ }^{3}$

Of course, Scott Rozelle and his colleagues at Stanford have demonstrated similar social problems in rural areas of China. ${ }^{4}$ So, it's important both for international relations and for China's own development that excellent education and entrepreneurial opportunities be spread widely throughout the country. This could help jump-start a beneficial cycle in which China's increasing indigenous innovation and more widespread prosperity could promote world technological innovation plus create new customers for American and other producers.

\footnotetext{
${ }^{3}$ These two books illustrate this point: "Deaths of Despair and the Future of Capitalism" written by Professor Anne Case and Professor Sir Angus Deaton and published by Princeton University Press in 2021. Also, "The Upswing" written by Professor Robert Putnam and published by Simon and Schuster in 2020.

4"Invisible China-How the Urban-Rural Divide Threatens China's Rise" written by Professor Scott Rozelle and Natalie Hell and published by University of Chicago Press in 2020.
} 
It is worth saying, however, that after China achieved what Walt Rostow ${ }^{5}$ dubbed "take-off into sustained growth" its economy soon became large relative to the countries with which it traded as measured by gross national product. As a consequence, China's gains from trade with America have generally lessened, so trade issues may become less pressing for both very large economies.

But, the world cannot ignore the opportunities created by China's move toward an economy driven by indigenous innovation. Imported innovation from America has had a net positive impact on China during the past four decades. The fact is that there is much less innovation coming out of the United States than there once was - and hardly any coming out of Europe. So China could become a major source of innovation for the global economy.

For its part, China's government is evidently supportive of Chinese businesses developing a capacity to produce indigenous innovations. It no doubt recognizes that such innovations are all the more valuable when innovation remains weak in the West, where growth in total factor productivity has continued its long slowdown.

But, thoughtful people still have questions and worries. In China, as well as the United States, a great deal of innovation is in industries making capital goods, infrastructure, or mining, but there is little innovation in industries such as clothing, housing, and healthcare. (In fact, data in the United States show that an index of prices of capital goods has been steadily falling for several decades.) It is natural to ask whether such narrowly focused innovation can go on very long. This suggests that companies aiming to innovate - in China, too-will ultimately run out of possibilities for innovation in that direction. In short, economies have to achieve broad innovation or they will have to settle for stagnation.

\section{What Policies Can Lead to More Dynamism?}

China has taken big steps to encourage entrepreneurship in the big cities, in rural areas and in small cities, and that is great. Yet, it's one thing to realize today's standards of productivity, and it's another thing to be generating new stuff all the time. So, China is going to need people who demonstrate their creativity by conceiving and introducing original things. Only this kind of indigenous innovation can lead to permanent growth.

Chinese businesspeople and entrepreneurs are increasingly showing not only the entrepreneurial drive to adapt to new opportunities but also the desire and capacity to innovate for themselves, rather than simply copying what is already out there. Indeed, more and more Chinese companies are realizing that they must innovate in order to get - and stay - ahead in the global economy. Chinese companies made breakthroughs by offering digital-age infrastructure that facilitates innovative activity, and industrial firms have recently moved into robots and artificial intelligence.

\footnotetext{
5"The Economics of Take-Off into Sustained Growth" written by Walt Rostow and published by Macmillan Palgrave in 1963.
} 
Huawei was the first Chinese company to dominate its market segment, with a $30 \%$ global market share in the key sector of telecommunications equipment, but it surely will not be the last. But this achievement has also occasioned alarm and suspicion in the United States.

One of the big surprises of the results in Dynamism ${ }^{6}$ is that during the so-called IT revolution, towering peaks either in the raw data on productivity or in our decomposed series of indigenous innovations were not detected. The United States could not restore a dynamic economy by relying on a small number of innovative firms in Silicon Valley - and the situation has worsened since those firms have become more oligopolistic and regularly employ anti-competitive practices.

When drawing up economic and social policies, we need to realize that people, in general, are capable of having original ideas, and many of these ideas might have commercial applications — not just scientists and high-tech engineers. Indeed, virtually every industry has had workers, managers, or others that hit upon new ideas at one time or another.

The implication is that indigenous innovation springs from the powers of originality and creativity among large numbers of people working in the nation's economy. In this thinking, a nation needs to possess the dynamism needed to create innovations and a willingness as a society to accept their introduction into the economy.

The sources and rewards of dynamism are tied up with the personal values that came to the fore during the period of innovation-led growth: the willingness to attempt innovation may be tied to developing conceptions of the "good life." This theory has grown out of work beginning soon after the founding of the Center on Capitalism and Society at Columbia University in $2001^{7}$ and culminating in Mass Flourishing and Dynamism. The fundamental thesis is that people from all walks of life possess inborn powers to conceive "new things," whether or not scientists have opened up new possibilities. An innovative society allows, even encourages, people to act on newly conceived things - to create them and try them.

What kinds of governmental policies can help a country reach the difficult goal of transformative, innovation-led growth? Of course, institutional reforms in the legal and financial systems along with programs to encourage R\&D and entrepreneurship are necessary, but they are not sufficient. Masses of people need to be encouraged to be innovative, creative, and dynamic. This is hard.

The exploration of new firms and new products in China in recent decades suggests that the Chinese do possess a dynamic spirit. Every time I visit China, I see energy and excitement among many people from many walks of life. But more reforms are still needed. To continue the progress and transformation, China will require leaders in government that continue to recognize the importance of both indigenous innovation as well as entrepreneurship, and, in turn, this will require policies to support people with imagination and ingenuity.

\footnotetext{
${ }^{6}$ 'Dynamism - The Values That Drive Innovation, Job Satisfaction, and Economic Growth' written by Edmund S. Phelps, Raicho Bojilov, Hian Teck Hoon, and Gylfi Zoega was published by Harvard University Press in 2020.

${ }^{7}$ https://capitalism.columbia.edu/about-center.
} 
In any nation where it takes hold, innovation-driven growth is immensely powerful. It transforms the nation from agricultural to industrial, from rural to urban, and from trading to producing. China appears to be on the verge of following this transformative path but cannot be complacent. Few countries have achieved growth led by indigenous innovation. The kind of social dynamism needed for growth driven by indigenous innovation is rare and easily stifled.

History suggests that dynamic economies are largely sparked by the original ideas of ordinary people using their creativity and imagination and developed by entrepreneurial people alert to new opportunities and keen to start new businesses that develop new concepts into commercial products and methods and then sell them to potential users. This is the China that I hope will emerge.

Edmund Phelps was awarded the 2006 Nobel laureate in Economics. He is Director of the Center on Capitalism and Society at Columbia University. He earned his B.A. at Amherst (1955), his $\mathrm{Ph} . \mathrm{D}$. at Yale (1959). He has written on growth, unemployment theory, recessions, stagnation, inclusion, rewards of employment, indigenous innovation, dynamism and the good economy. His work can be seen as a lifelong project to put "people as we know them" into economic theory. His most recent books include Mass Flourishing (2013), and Dynamism (2020). In 2018 he was named among China's 40 most influential foreign experts by the State Administration of Foreign Experts.

Open Access This chapter is licensed under the terms of the Creative Commons AttributionNonCommercial-NoDerivatives 4.0 International License (http://creativecommons.org/licenses/bync-nd/4.0/), which permits any noncommercial use, sharing, distribution and reproduction in any medium or format, as long as you give appropriate credit to the original author(s) and the source, provide a link to the Creative Commons license and indicate if you modified the licensed material. You do not have permission under this license to share adapted material derived from this chapter or parts of it.

The images or other third party material in this chapter are included in the chapter's Creative Commons license, unless indicated otherwise in a credit line to the material. If material is not included in the chapter's Creative Commons license and your intended use is not permitted by statutory regulation or exceeds the permitted use, you will need to obtain permission directly from the copyright holder.

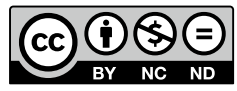

